\title{
CALCIURIA IN CHILDREN WITH PRIMARY MONO-SYMPTOMATIC NOCTURNAL ENURESIS
}

\author{
Mulić Bilsana, ${ }^{1}$ Mulić Mersiha, ${ }^{2}$ Muminović Suada, ${ }^{3}$ Mulić Mersudin, ${ }^{4}$ \\ Vujošević Snežana, ${ }^{5}$ Peco-Antić Amira ${ }^{6}$ \\ ${ }^{1}$ Novi Pazar General Hospital, Pediatric Department, Novi Pazar, Serbia \\ ${ }^{2}$ University of Belgrade, Faculty of Medicine, Belgrade, Serbia \\ ${ }^{3}$ Community Health Centre Tutin, Tutin, Serbia \\ ${ }^{4}$ State University of Novi Pazar, Novi Pazar, Serbia \\ ${ }^{5}$ Departmemt of endocrinology, Clinical center of Montenegro, Podgorica, Montenegro \\ ${ }^{6}$ BelMedic Belgrade, Belgrade, Serbia
}

Primljen/Received 20. 10. 2018. god.

Abstract: Introduction: The prevalence of idiopathic hypercalciuria $(\mathrm{IH})$ in healthy pediatric population ranges from $3.0 \%$ to $7.0 \%$. There is insufficient data about IH in children with mono-symptomatic enuresis. The aim of this study was to examine calcium excretion in urine (UCa) in patients with primary mono-symptomatic nocturnal enuresis (PMNE). Methods: In patients with PMNE, aged 5 to 17 years, IH was determined in 24-h urine and from second morning spot urine. The completeness of the 24-h urine collections was estimated via measuring $24 \mathrm{~h}$-urine creatinine excretion (UCr) of $0.1-0.2 \mathrm{mmol} / \mathrm{kg} / 24 \mathrm{~h}$. Results: Sixty patients with PMNE, 32 males and 28 girls, median age of 9 years were enrolled in the study. Only $41.7 \%$ patients successfully completed $24 \mathrm{~h}$ urine collection. $\mathrm{IH}$, defined as $24-\mathrm{h} \mathrm{UCa}>0.1 \mathrm{mmol} / \mathrm{kg}$ body weight, was diagnosed in $12 \%$ of the patients, while when defined as $\mathrm{UCa} / \mathrm{UCr}>0.8 \mathrm{mmol} / \mathrm{mmol}$ in children $5-7$ years and $>0.6 \mathrm{mmol} / \mathrm{mmol}$ in those $>7$ years, IH was $8.3 \%$ and $6.7 \%$ from $24 \mathrm{~h}$ - urine and spot urine, respectively. Conclusion: Children and adolescents with PMNE are in risk of hypercalciuria. Therefore, it is useful to examine 24 hours of urine calcium excretion in these patients.

Key words: Idiopathic hypercalciuria; collection of $24 \mathrm{~h}$-urine; enuresis.

\section{INTRODUCTION}

Nocturnal enuresis or bedwetting is an involuntary voiding during sleep in children aged more than 5 years. It is a primary when children have never achie-
Prihvaćen/Accepted 01. 12. 2018. god.

ved six months of continuously dry nights, or it is a secondary which occur after at least 6 months of nighttime voiding control. Nocturnal enuresis is common in children. However, its prevalence decreases with increasing age of the child. The Avon Longitudinal Study of Parents and Children found that the prevalence of bedwetting $<2$ nights per week is $30 \%$ at age of 4.5 years and $8 \%$ at 9.5 years, and the prevalence of bedwetting $\geq 2$ nights per week is $8 \%$ at 4.5 years and $1.5 \%$ at 9.5 years (1). In another studies, about $10 \%$ of all 7 -yr-old children, $5 \%$ of all 10 -yr-olds and $0.5-1 \%$ of adults were affected more than three times bedwetting per week $(2,3)$.

Nocturnal enuresis is very distressing condition that can have a deep impact on the child/young person's behavior and on their emotional and social life $(4,5)$. It also disturbs a quality of life among the parents or guardians (6).

According to the Standardization Committee of the International Children's Continence Society (ICCS) the term mono-symptomatic nocturnal enuresis (MNE) signifies that children have enuresis only when asleep while the term non-mono-symptomatic nocturnal enuresis (NMNE) describes the symptoms of children who have urinary incontinence at night and also have day time voiding symptoms (7). An estimated 80 percent of children with nocturnal enuresis have MNE form.

The pathophysiology of primary MNE (PMNE) is complex and so far it has not yet been fully clarified. An altered circadian profile of antidiuretic hormone, arousal failure and delayed urinary bladder maturation are the best studied pathophysiological factors (8). 
Kamperis et al. documented that polyuric patients with MNE refractory to desmopressin treatment excrete larger amounts of sodium and urea at night compared with healthy controls and nonpolyurics MNE patients despite a normal the circadian rhythm of sodium-regulating hormones such as atrial natriuretic peptide, angiotensin II, aldosterone, and renin levels but may be secondary to augmented urinary prostaglandin E2 (PGE2) excretion (9). Some authors found idiopathic hypercalciuria $(\mathrm{IH})$ to be more common in children with PMNE than in children without nocturnal enuresis and for this reason they assume that IH could be one of the contributing pathophysiologic factor to PMNE $(10,11,12)$.

Considering $24 \mathrm{~h}$-variations in urine calcium excretion, the diagnosis of hypercalciuria is most accurately determined from the urine collected for $24 \mathrm{~h}$. This is usually difficult to achieve in children who have nocturnal enuresis. In situations where 24h-urine collection is not possible, random urine measurements are implemented, using spot urine ratio of the calcium and creatinine and comparing it with its age-related reference values $(10,13)$.

The aim of this study was to examine calcium excretion in urine collected for 24 hours and from the second morning spot urine in children and adolescents with PMNE, and to estimate the frequency of hypercalciuria.

\section{MATERIAL AND METHODS}

All consecutive children and adolescents referred from September 2017 to May 2018 to Pediatric Hospital in Novi Pazar (a city located in the Raška District of southwestern Serbia), due to nocturnal enuresis, were considered to be included in this study. Inclusion criteria for the study were: 1) Patients with PMNE, age 5 to 17 years, 2) completed 24-h urine collection, 3) normal renal function and 4) normal serum electrolytes including calcium level. Exclusion criteria were as follows: (1) urinary tract infections in anamnesis, (2) signs of any acute infection before examination, (3) secondary nocturnal enuresis, and NMNE, (4) no idiopathic hypercalciuria, (5) metabolic diseases, (6) renal stone diseases, (7) impaired kidney function, (8) kidney and urinary tract anomalies, (9) and any pharmacological treatment or diet supplementation in past 6 months (calcium, Vitamin D).

The clinical work up were done in all patients consisting of collecting data to determine age, gender, present and past medical history, daytime and nighttime voiding patterns, bowel emptying habits, family history for nocturnal enuresis and renal stone diseases, and complete physical examination. Laboratory analyzes that inclu- ded serum urea, creatinine, complete blood count, fasting blood sugar and electrolytes, urinary electrolytes and creatinine levels were tested in all patients. Kidney and bladder ultrasound were also done. Twenty-four hour urine samples were collected for each patient to measure calcium (UCa) and creatinine (UCr). To prevent urine loss the enuretic children were waking up at least two times during night. The completeness of the 24-h urine collections was estimated via measuring $24 \mathrm{~h}$-urine creatinine of $0.1-0.2 \mathrm{mmol} / \mathrm{kg} / 24 \mathrm{~h}$ (14). Urine calcium from $24 \mathrm{~h}$ urine was expressed in $\mathrm{mmol} / \mathrm{kg}$ body weight (BW) and in mmol/1 per kg BW. UCa and UCr were determined also in spot urine from second urine sample. Urinary tract infections were excluded on the basis of urinary testing.

PMNE was defined as involuntary nocturnal bedwetting $\geq$ twice a week for $\geq 3$ consecutive months in children of $\geq 5$ years of age who have never gained control over night time voiding, but without any low urinary tract problems during the daytime. Idiopathic hypercalciuria (IH) was diagnosed if urine calcium excretion was $\geq 0.1 \mathrm{mmol} \mathrm{kg}$ /day in the $24 \mathrm{~h}$ urine or urine calcium to creatinine ratio of more than $0.6 \mathrm{mmol} / \mathrm{mmol}$ in urine samples in children aged $>7$ years and $>0.8 \mathrm{mmol} / \mathrm{mmol}$ in those aged 5-7 years (10). Patients were divided into two groups, the first (I) consisted of normocalciuric children with PMNE and the second one (II) included hypercalciuric children with PMNE. The demographic data, urine calcium level as well as family history for nocturnal enuresis and renal stone diseases were compared between groups. Data analysis was performed using SPSS version 21 software. Normal distribution of data was tested with the Shapiro-Wilk W test. Quantitative variables were provided as median and interquartile (IQR) range, while qualitative ones were presented as a percentage. The variables were compared using Student's " $t$ " test, Mann-Whitney U-test and chi-square test, where it was appropriate. A p value < 0.05 was considered statistically significant.

Written informed consent was obtained from all the enrolled subjects, subsequent to receive full information about the study. The study was approved by the Ethics Committee of General Hospital Novi Pazar in accordance with the Declaration of Helsinki.

\section{RESULTS}

Sixty patients with PMNE, 32 males and 28 girls, median age of 9 (IQR 7.0-12.7) years were enrolled in the study. Only 25 (41.66\%) patients successfully completed $24 \mathrm{~h}$ urine collection with median $24-\mathrm{h} \mathrm{UCr}$ of 0.16 (IQR 0.12-0.18). Hypercalciuria, defined for all ages as $24-\mathrm{h} \mathrm{Ucr}>0.1 \mathrm{mmol} / \mathrm{kg}$ body weight, was diagnosed in three patients (12\%). Clinical characteris- 
Table 1. Clinical sharacteristics of the patients with PMNE who successfully completed 24h-urine collections

\begin{tabular}{|c|c|c|c|c|}
\hline Parameters & $\begin{array}{l}\text { All patients } \\
\mathrm{n}=\mathbf{2 5}\end{array}$ & $\begin{array}{c}{ }^{*} \text { Group I } \\
\mathbf{n}=\mathbf{3}\end{array}$ & $\begin{array}{c}\text { Group II } \\
n=22\end{array}$ & $\begin{array}{c}\text { Comparisons between } \\
\text { groups I and II }\end{array}$ \\
\hline Gender, Males (\%) & $15(60.0)$ & $2(66.7)$ & $13(59.1)$ & ns \\
\hline Age in years, Median (IQR) & $8.00(7.00-10.50)$ & $8(7.00-8.00)$ & $8.00(7.00-10.25)$ & ns \\
\hline Body height $(\mathrm{cm})$, Median (IQR) & $125.00(121.30-141.65)$ & $123.60(121.50-123.60)$ & $125.15(118.97-140.12)$ & ns \\
\hline Body weight (kg), Median (IQR) & $29.00(21.70-36.00)$ & $26.00(22.90-26.00)$ & $19.50(21.37-35.50)$ & ns \\
\hline Body mass index $\left(\mathrm{kg} / \mathrm{m}^{2}\right)$, Median (IQR) & $18.47(15.47-19.45)$ & $17.30(15.57-17.30)$ & $18.48(15,28-19.37)$ & ns \\
\hline UCa in $24 \mathrm{~h}$ urine (mmol/kg), Median (IQR) & $0.06(0.01-0.05)$ & $0.13(0.12-0.13)$ & $0.01(0.01-0.05)$ & $\mathrm{p}=0.001$ \\
\hline $\mathrm{UCa}(\mathrm{mmol} / \mathrm{l}) / \mathrm{kg} \mathrm{BW}$ & $0.05(004-0.08)$ & $0.12(0.07-0.12)$ & $0.04(0.04-0.06)$ & $\mathrm{p}=0.027$ \\
\hline UCr in $24 \mathrm{~h}$ urine $(\mathrm{mmol} / \mathrm{kg})$, Median (IQR) & $0.16(0.12-0.18)$ & $0.17(0.11-0,17)$ & $0.15(0.012-0.18)$ & ns \\
\hline $\mathrm{UCa} / \mathrm{UCr}$ in $24 \mathrm{~h}$ urine $(\mathrm{mmol} / \mathrm{mmol})$, Median (IQR) & $0.33(0.29-0.43)$ & $0.59(0.40-0.59)$ & $0.31(0.28-0.040)$ & $\mathrm{p}=0.014$ \\
\hline $\mathrm{Ca} / \mathrm{Cr}$ spot urine (mmol/mmol), Median (IQR) & $0.29(0.17-0.38)$ & $0.52(0.16-0.52)$ & $0.28(0.17-0.35)$ & ns \\
\hline $\begin{array}{l}\text { Hipercalciuria according to UCa/UCr in } 24 \text { h urine } \\
(\mathrm{mmol} / \mathrm{mmol})(\%)\end{array}$ & $1(4.0 \%)$ & $1(33.33)$ & $0(0)$ & $p=0.006$ \\
\hline $\begin{array}{l}\text { Hipercalciuria according } \mathrm{UCa} / \mathrm{UCr} \text { spot urine } \\
(\mathrm{mmol} / \mathrm{mmol})(\%)\end{array}$ & $1(4.0 \%)$ & $1(33.33)$ & $0(0)$ & $\mathrm{p}=0.006$ \\
\hline Positive family history for nocturnal enuresis (\%) & $14(56.0 \%)$ & $2(66.70)$ & $12(54.50)$ & ns \\
\hline Positive family for nephrolithiasis (\%) & $1(4 \%)$ & $0(0)$ & $1(4.50 \%)$ & ns \\
\hline
\end{tabular}

PMNE $=$ Primary monosymptomatice nocturnal enuresis; IQR = interquartile range (25-75 percentile), * For group I IQR was presented only as 25 and 50 percentile due to small number of the patients; $\mathrm{UCa}=$ Calcium in urine; $\mathrm{UCr}=$ creatinine in urine; $\mathrm{UCa} / \mathrm{UCr}$ $=$ ratio of urinary calcium and creatinine; $\mathrm{ns}=$ not significant

Table 2. Comparative analysis between patients with and without hypercalciuria based on UCa / UCr from $24 \mathrm{~h}$ urine or spot urine

\begin{tabular}{|c|c|c|c|c|c|c|}
\hline \multirow[b]{2}{*}{$\begin{array}{l}\text { Parameters, } \\
\text { Median (IQR) }\end{array}$} & \multirow{2}{*}{$\begin{array}{c}\text { Group 1 } \\
\text { Patients with } \\
\text { increased UCr/UCa in } \\
\begin{array}{c}24 \mathrm{~h} \text { urine, } \\
\mathrm{n}=5\end{array}\end{array}$} & \multirow[b]{2}{*}{$\begin{array}{c}\text { Group } 2 \\
\text { Patients with normal } \\
\mathrm{UCr} / \mathrm{UCa} \text { in } 24 \mathrm{~h} \text { urine } \\
\mathrm{n}=\mathbf{5 5}\end{array}$} & \multirow{2}{*}{\begin{tabular}{|c} 
Group 3 \\
Patients with \\
increased $\mathrm{UCr} / \mathrm{UCa}$ in \\
spot urine, \\
$\mathrm{n}=4$
\end{tabular}} & \multirow[b]{2}{*}{$\begin{array}{c}\text { Group } 4 \\
\text { Patients with normal } \\
\text { UCr/UCa in spot urine } \\
\mathbf{n}=\mathbf{5 6}\end{array}$} & \multicolumn{2}{|c|}{ Comparisons } \\
\hline & & & & & $\begin{array}{c}\text { Group } 1 \\
\text { vs } \\
\text { Group } 2\end{array}$ & $\begin{array}{l}\text { Group } 3 \\
\text { vs } \\
\text { Group } 4\end{array}$ \\
\hline Gender, Males (\%) & $3(60 \%)$ & $29(52.7 \%)$ & $1(25)$ & $31(55.4)$ & ns & ns \\
\hline Age in years, & $7(6.0-10.50)$ & $10(7.0-13.0)$ & $5.75(5.50-11.25)$ & $9.5(7.00-12.75)$ & ns & ns \\
\hline Body height $(\mathrm{cm})$ & $117.6(111.50-137.15)$ & $132.6(115.30-150.20)$ & $107.80(103.75-139.07)$ & $131.60117 .60-149.95)$ & ns & ns \\
\hline Body weight (kg) & $31.0(22.5-41.0)$ & $33.0(22.90-42.60)$ & $21.35(19.17-42.50)$ & $33.00(23.25-43.57)$ & ns & ns \\
\hline Body mass index $\left(\mathrm{kg} / \mathrm{m}^{2}\right)$ & $19.4(18.0-23.1)$ & $18.8(17.30-20.00)$ & $18.40(17.87-21.40)$ & $18.93(17.35-20.00)$ & ns & ns \\
\hline $\begin{array}{l}\text { UCa in } 24 \mathrm{~h} \text { urine } \\
(\mathrm{mmol} / \mathrm{kg}), \text { Median }(\mathrm{IQR}))\end{array}$ & $0.06(0.05-0.10)$ & $0.01(0.01-0.03)$ & $0.03(0.02-0.10)$ & $0.10(0.001-0.045)$ & $p=0.003$ & ns \\
\hline $\mathrm{UCa}(\mathrm{mmol} / \mathrm{l}) / \mathrm{kgBW}$ & $0.07(0.06-0.10)$ & $0.03(0.02-0.03)$ & $0.04(0.02-0.10)$ & $0.06(0.02-0.06)$ & $\mathrm{p}=0.007$ & ns \\
\hline $\mathrm{UCr}$ in $24 \mathrm{~h}$ urine $(\mathrm{mmol} / \mathrm{kg})$ & $0.09(0.08-0.10)$ & $0.09(0.07-0.15)$ & $0.06(0.05-0.10)$ & $0.10(0.07-0,15)$ & ns & ns \\
\hline $\begin{array}{l}\mathrm{UCa} / \mathrm{Ucr} \text { in } 24 \mathrm{~h} \text { urine } \\
(\mathrm{mmol} / \mathrm{mmol})\end{array}$ & $0.7(0.66-0.94)$ & $0.33(0.25-0.40)$ & $0.53(0.04-0.99)$ & $0.33(0.25-0.41)$ & $p=0.000$ & $p=0.012$ \\
\hline $\begin{array}{l}\text { UCa/UCr in spot urine } \\
(\mathrm{mmol} / \mathrm{mmol}) \text { Median (IQR) }\end{array}$ & $0.54(0.24-0.65)$ & $0.29(0.18-0.41)$ & $0.69(0.62-0.94)$ & $0.29(0.17-0.39)$ & ns & 0.000 \\
\hline $\begin{array}{l}\mathrm{UCa} \text { in } 24 \mathrm{~h} \text { urine }>0.1 \\
\mathrm{mmol} / \mathrm{kg} / 24 \mathrm{~h}\end{array}$ & $1(20)$ & $3(5.45)$ & $2(50)$ & $3(5.36)$ & $\mathrm{p}=0.027$ & ns \\
\hline $\begin{array}{l}\text { UCa/UCr in spot urine }>0.6 \\
(\mathrm{mmol} / \mathrm{mmol})\end{array}$ & $2(40.0)$ & $2(3.64)$ & $4(100)$ & $0(0)$ & ns & $\mathrm{p}=0.000$ \\
\hline $\begin{array}{l}\text { Positive family history for } \\
\text { nocturnal enuresis }(\%)\end{array}$ & $2(40.0)$ & $24(43.6)$ & $3(75)$ & $23(41.1)$ & ns & ns \\
\hline $\begin{array}{l}\text { Positive family for } \\
\text { nephrolithiasis (\%) }\end{array}$ & $0(0)$ & $7(12.7)$ & $1(25)$ & $6(10.7)$ & ns & ns \\
\hline
\end{tabular}

$\mathrm{IQR}=$ interquartile range $(25-75$ percentile $) ; \mathrm{UCa}=$ Calcium in urine; $\mathrm{UCr}=$ creatinine in urine; $\mathrm{UCa} / \mathrm{UCr}=$ ratio of urinary calcium and creatinine; $n s=$ not significant 
tics of the patients with (group I) and without (group II) hypercalciuria are presented in Table 1 . There were no statistically significant differences between these groups neither in age, gender, body height (BH), body weight (BW), body mass index (BMI), nor in family history for NE and renal stone diseases. As expected the patients with $\mathrm{IH}$ had significantly higher $\mathrm{UCa}$ and $\mathrm{UCa} / \mathrm{UCr}$ in $24 \mathrm{~h}$ - urine. In addition, the median $24 \mathrm{~h}$ urine calcium $(\mathrm{mmol} / \mathrm{l}) /$ body weight $(\mathrm{kg})$ ratio was also higher in the group I than in the group II.

Urine calcium/creatinine ratio in spot urine was higher in group I than in group II, but the difference did not reach statistical significance. Only one patient, who belongs to group I had increased ratio of urinary $\mathrm{Ca}$ and creatinine from 24h-urine as well as from spot urine.

Hypercalciuria may be diagnosed also according to $\mathrm{UCa} / \mathrm{UCr}$ ratio when it is $>0.8 \mathrm{mmol} / \mathrm{mmol}$ in children aged $5-7$ years and $>0.6 \mathrm{mmol} / \mathrm{mmol}$ in those aged $>7$ years. Using these criteria for $24 \mathrm{~h}-$ urine and for spot urine hypercalciuria was found in $8.33 \%$ and $6.67 \%$ of all patients with PMNE, respectively (See Table 2). In addition, the median $24 \mathrm{~h}$ urine calcium expressed in $\mathrm{mmol} / \mathrm{l}$ and body weight ratio was higher in the group with hypercalciuria (group 1) than in the group with normal calciuria (group 2).

A positive family history of nocturnal enuresis was found in 40 to $60.7 \%$ of patients, depending on how they were classified. In contrast, a positive history of nephrolithiasis was found in a significantly smaller number $(0 \%$ to $12 \%)$ of patients.

\section{DISCUSSION}

Idiopathic hypercalciuria $(\mathrm{IH})$ is defined by hypercalciuria, normocalcemia, and the absence of diseases known to cause increased urine calcium excretion (15). Pathogenesis of IH is very complex and many potential factors can be involved, such as polymorphisms of the gene coding for proteins regulating tubular phosphate and calcium reabsorption and those responsible for proteins preventing calcium salt precipitation or gene coding for a water channel in the proximal tubule (16). Furthermore, in families with an autosomal dominant mode of $\mathrm{IH}$, inheritance connection between IH and loci on chromosome 1q23.3-q24, which contains the human soluble adenylyl cyclase gene, chromosome 12q12-q14, which contains the VDR gene and chromosome 9q33.2-q34.2, were established (17). Environmental factors may also significantly affect renal stone formation. Nutrient intake may change urine composition, but may also influence gene expression by epigenetic mechanisms.

The idea that IH may be an important pathogenic factor of nocturnal enuresis was first proposed by Pace et al. (18) who noted that a proportion of enuretic children had absorptive hypercalciuria. Since that time some strategies were made to measure urinary calcium excretion in the evaluation of nocturnal enuresis $(19,20)$. It has come so far that the therapeutic response of desmopressin link to the reduction of hypercalciuria as has been demonstrated in some Italian studies $(21,22)$. However, there are opposing opinions about the possible relationship between hypercalciuria and enuresis. Neveus et al. in their study concluded that the urinary calcium excretion does not differ between enuretic and dry children (23). Kamperis et al. in another study observed no significant difference among calcium excretion of children with or without nocturnal enuresis (24). Different data on the frequency of IH in children with nocturnal enuresis can be explained by heterogeneity in its etiopatogenesis as well as by differences in the methodology of testing or measurement of calcium in the urine.

It is well known that hypercalciuria can be presented with different symptoms associated with urinary symptoms $(25,26)$. Recently, Esteghamati et al found the prevalence of idiopathic hypercalciuria is $48.3 \%$ in children with urinary tract infection, $54.9 \%$ and $53.6 \%$ in children with microscopic and macroscopic hematuria respectively, $52.1 \%$ and $51.8 \%$ in children with dysuria and in children with frequency respectively, $49.1 \%$ in children with kidney stone, and $28.6 \%$ and $37.5 \%$ in children with nocturnal and daily urinary incontinency respectively (27). There is insufficient data about IH in monosymptomatic enuresis.

In the present study we found hypercalciuria in $12 \%$ of the patients with PMNE when calcium in urine was determined in properly collected $24 \mathrm{~h}$ urine, but only in $8 \%$ and in $6.7 \%$ of the patients when it was estimated on the basis of calcium and creatinine ratio in 24 $h$ and spot urine, respectively. The prevalence of IH in the healthy pediatric population is considerable, and the authors have reported rates between $3.0 \%$ and $7.0 \%$ among children $(26,28)$. Our data confirmed the greater sensitivity of calciuria from $24 \mathrm{~h}$ urine compared to spot urine calciuria. Although the determination of calciuria is much more reliable at $24 \mathrm{~h}$ urine, proper urine collection for $24 \mathrm{~h}$ is very difficult to perform in children with bedwetting. Only $41.7 \%$ of our patients managed to properly collect the urine for $24 \mathrm{~h}$. Like other authors (29) we found a strong family history of bedwetting in children and adolescents with PMNE.

Our study has some limitations. One of the limitations in this study was the difficulty of 24-hour urine collection, and, therefore a relatively small number of patients with PMNE who succeed urine collection. Another limitation of the study is the lack of a control group. We suggest that IH in children with PMNE should be examined from $24 \mathrm{~h}$ urine in a larger group of children. 


\section{CONCLUSION}

Children and adolescents with primary monosymptomatic nocturnal enuresis are in risk of hypercalciuria. It is therefore useful to examine 24 hours of urine calcium excretion in these patients.

\footnotetext{
Abbreviations

PMNE - Primary monosymptomatic nocturnal enuresis

IQR - interquartile range (25-75 percentile)

* For group I IQR was presented only as 25 and 50 percentile due to small number of the patients
}

UCa - Calcium in urine

$\mathbf{U C r}$ - creatinine in urine

$\mathrm{UCa} / \mathrm{UCr}$ - ratio of urinary calcium and creatinine

ns - not significant

\section{DECLARATION OF INTEREST}

The authors declare that there are no conflicts of interests.

\section{Licensing}

This work is licensed under a Creative Commons Attribution 4.0 International (CC BY 4.0) License.

\title{
Sažetak
}

\section{KALCIURIJA KOD DECE SA PRIMARNOM MONOSIMPTOMATSKOM NOĆNOM ENUREZOM}

\author{
Mulić Bilsana, ${ }^{1}$ Mulić Mersiha, ${ }^{2}$ Muminović Suada, ${ }^{3}$ Mulić Mersudin, ${ }^{4}$ \\ Vujošević Snežana, ${ }^{5}$ Peco-Antić Amira ${ }^{6}$ \\ ${ }^{1}$ Novi Pazar General Hospital, Pediatric Department, Novi Pazar, Serbia \\ ${ }^{2}$ University of Belgrade, Faculty of Medicine, Belgrade, Serbia \\ ${ }^{3}$ Community Health Centre Tutin, Tutin, Serbia \\ ${ }^{4}$ State University of Novi Pazar, Novi Pazar, Serbia \\ ${ }^{5}$ Departmemt of endocrinology, Clinical center of Montenegro, Podgorica, Montenegro \\ ${ }^{6}$ BelMedic Belgrade, Belgrade, Serbia
}

Uvod/Cilj: Prevalencija idiopatske hiperkalciurije (IH) se u zdravoj pedijatrijskoj populaciji kreće od 3.0\% do $7.0 \%$. Nema dovoljno podataka o IH u dece sa monosimptomatskom enurezom. Cilj studije je bio da ispita izlučivanje kalcijuma u urinu (UCa) kod dece sa primarnom monosimptomatskom noćnom enurezom (PMNE). Materijal i metode: IH je ispitana kod dece sa PMNE, uzrasta 5 do 17 godina, iz urina skupljenog za 24 časa (h ) i iz drugog jutarnjeg uzorka urina. Kompletnost skupljanja $24 \mathrm{~h}$ urina je procenjena na osnovu izlučivanja kreatinina u urinu (UCr) od 0.1 do $0.2 \mathrm{mmol} / \mathrm{kg} / 24 \mathrm{~h}$. Rezultati: Šezdeset pacijenata sa PMNE, 32 dečaka i 28

\section{REFERENCES:}

1. Butler RJ, Heron J. The prevalence of infrequent bedwetting and nocturnal enuresis in childhood. A large British cohort. Scand J Urol Nephrol. 2008; 42(3): 257-64.

2. Sarici H, Telli O, Ozgur BC, Demirbas A, Ozgur S, Karagoz MA. Prevalence of nocturnal enuresis and its influence on quality of life in school-aged children. J Pediatr Urol. 2016; 12(3): 159:e1-6.

3. Franco I, von Gontard A, De Gennaro M. International Children's Continence Society. Evaluation and treatment of nonmonosymptomatic nocturnal enuresis: a standardization document from the international children's continence society. J Pediatr Urol. 2013; 9: 234-43. devojčica prosečnog uzrasta 9 godina je ispitano u studiji. Samo 41.7\% bolesnika uspešno je skupilo $24 \mathrm{~h}$ urin. $\mathrm{IH}$, definisana kao UCa $>0.1 \mathrm{mmol} / \mathrm{kg}$ telesne težine/ 24-h, dijagnostikovana je kod $12 \%$ pacijenata, dok IH definisana $\mathrm{kao} \mathrm{UCa} / \mathrm{UCr}>0.8 \mathrm{mmol} / \mathrm{mmol} \mathrm{kod}$ dece 5-7 godina i $>0.6 \mathrm{mmol} / \mathrm{mmol}$ kod onih $>7$ godina, $\mathrm{IH}$ je bila $8.3 \%$ i $6.7 \%$ izmerena u $24 \mathrm{~h}$ - urinu i jutarnjem uzorku urina. Zaključak: Deca i adolescenti sa PMNE su u riziku za hiperkalciuriju. Stoga je korisno kod njih ispitati izlučivanje kalcijuma u urinu.

Ključne reči: Idiopatska hiperkalciurija, skupljanje 24 časovnog urina, umokravanje.

4. Reddy NM, Malve H, Nerli R, Venkatesh P, Agarwal I, Rege V. Nocturnal Enuresis in India: Are We Diagnosing and Managing Correctly? Indian J Nephrol. 2017; 27(6): 417-26.

5. Kilicoglu AG, Mutlu C, Bahali MK, Adaletli H, Gunes $\mathrm{H}$, Duman HM, et al. Impact of enuresis nocturna on health-related quality of life in children and their mothers. J Pediatr Urol. 2014; 10(6): 1261-6.

6. Durmaz O, Kemer S, Mutluer T, Bütün E. Psychiatric dimensions in mothers of children with primary nocturnal enuresis: A controlled study. J Pediatr Urol. 2017; 13(1): 62.e1-62.e6.

7. Austin PF, Bauer SB, Bower W, Chase J, Franco I, Hoebeke $\mathrm{P}$, et al. The standardization of terminology of lower urinary tract function in children and adolescents: Update report 
from the standardization committee of the International Children's Continence Society. Neurourol Urodyn. 2016; 35: 471-81.

8. Haid B, Tekgül S. Primary and secondary enuresis: pathophysiology, diagnosis, and treatment. Eur Urol Focus. 2017; 3(2-3): 198-206

9. Kamperis K, Rittig S, Jrgensen KA, Djurhuus JC. Nocturnal polyuria in monosymptomatic nocturnal enuresis refractory to desmopressin treatment. Am J Physiol Renal Physiol. 2006; 291(6): F1232-40.

10. Korzeniecka-Kozerska A, Porowski T, Wasilewska A, Stefanowicz M. Urinary calcium excretion in children with monosymptomatic enuresis. Ir J Med Sci. 2015; 184(4): 899-905.

11. Civilibal M, Selcuk Duru N, Elevli M, Civilibal N. Hypercalciuria in children with monosymptomatic nocturnal enuresis. J Pediatr Urol. 2014; 10(6): 1145-8.

12. Yousefichaijan P, Sharafkhah M, Cyrus A, Rafeie M. Therapeutic Efficacy of Hydrochlorothiazide in Primary Monosymptomatic Nocturnal Enuresis in Boys With Idiopathic Hypercalciuria. Nephrourol Mon. 2015; 7(5): e29127.

13. Issler N, Dufek S, Kleta R, Bockenhauer D, Smeulders N, van't Hoff W. Epidemiology of paediatric renal stone disease: a 22-year single centre experience in the UK. BMC Nephrol. 2017; 18(1):136.

14. Remer T, Neubert A, Maser-Gluth C. Anthropometry-based reference values for 24-h urinary creatinine excretion during growth and their use in endocrine and nutritional research. Am J Clin Nutr. 2002; 75(3): 561-9.

15. Peco-Antić A. Pediatric renal stone disease. Srp Arh Celok Lek. 2018; 146(3-4): 218-25.

16. Arcidiacono A, Mingione A, Macrina L, Pivari F, Soldati L, Vezzoli G. Idiopathic calcium nephrolithiasis: a review of pathogenic mechanisms in the light of genetic studies. Am J Nephrol. 2014; 40(6): 499-506.

17. Sayer JA. Progress in understanding the genetics of calcium containing nephrolithiasis. J Am Soc Nephrol. 2017; 28(3): 748-59.

18. Pace G, Aceto G, Cormio L, Traficante A, Tempesta A, Lospalluti ML, et al. Nocturnal enuresis can be caused by absorptive hypercalciuria. Scand J Urol Nephrol. 1999; 33(2): 111-4.
19. Raes A, Dossche L, Hertegonne N, Nuytemans L, Hoebeke P, Van Laecke E et al. Hypercalciuria is related to osmolar excretion in children with nocturnal enuresis. J Urol. 2010; 183(1) :297-301.

20. Valenti G, Laera A, Pace G, Aceto G, Lospalluti ML, Penza R, et al. Urinary aquaporin 2 and calciuria correlate with the severity of enuresis in children. J Am Soc Nephrol. 2000; 11(10): 1873-81.

21. Aceto G, Penza R, Coccioli MS, Palumbo F, Cresta L, Cimador M, et al. Enuresis subtypes based on nocturnal hypercalciuria: a multicenter study. J Urol. 2003; 170(4Pt 2): 1670-3.

22. Valenti G, Laera A, Gouraud S, Pace G, Aceto G, Penza $\mathrm{R}$, et al. Low-calcium diet in hypercalciuric enuretic children restores AQP2 excretion and improves clinical symptoms. Am J Physiol Renal Physiol. 2002; 283(5): F895-903.

23. Nevéus T, Hansell P, Stenberg A. Vasopressin and hypercalciuria in enuresis: a reappraisal. BJU Int. 2002; 90(7): $725-9$.

24. Kamperis K, Hagstroem S, Rittig S, Djurhuus JC. Urinary calcium excretion in healthy children and children with primary monosymptomatic nocturnal enuresis. J Urol. 2006; 176(2): 770-3.

25. Heiliczer JD, Canonigo BB, Bishof NA, Moore ES. Non calculi urinary tract disorders secondary to idiopathic hypercalciuria in children. Pediatr Clin North Am. 1987; 34(3): $711-8$.

26. Balestracci A, Meni Battaglia L, Toledo I, Martin SM, Wainsztein RE. Idiopathic hypercalciuria in children with urinary tract infection. Arch Argent Pediatr. 2014; 112(5): 428-33.

27. Esteghamati M, Ghasemi K, Nami M. Prevalence of idiopathic hypercalciuria in children with urinary system related symptoms attending a pediatric hospital in Bandar Abbas in 2014. Electron Physician. 2017; 9(9): 5261-4.

28. Gül A, Özer S, Y2lmaz R, Sönmezgöz E, Kasap T, Takç2 S, et al. Prevalence of hypercalciuria and urinary calcium excretion in school-aged children in the province of Tokat. Turk Pediatri Ars. 2016; 51(4): 193-7.

29. Arda E, Cakiroglu B, Thomas DT. Primary nocturnal enuresis: r Review. Nephrourol Mon. 2016; 8(4): e35809.

\section{Correspondence to/Autor za korespondenciju}

Bilsana Mulić

Novi Pazar General Hospital, Pediatric Department

Generala Živkovića 1

36300 Novi Pazar, Serbia

email: emmulic@mts.rs 